\title{
Anti-Ulcerogenic Potential of Aqueous Extract of Securinega virosa Leaf in Indomethacin-Induced Ulcerated Rats
}

\author{
Musa O. SALAWU*, Abdsamad YEKEEN, Mikhail O. NAFIU, \\ Hussein O. B. OLOYEDE \\ University of Ilorin, Faculty of Life Sciences, Department of Biochemistry, Ilorin, Kwara State, \\ Nigeria; salawu.mo@unilorin.edu.ng( ${ }^{*}$ correspondingauthor);yekeenas@gmail.com; olumikail@gmail.com; oboloyede@yahoo.com
}

\begin{abstract}
The anti-ulcerogenic activities of Securinega virosa aqueous leaf extract on gastric ulcer induced with indomethacin in albino rats were studied. Thirty rats weighing 120-200 g were grouped into six groups of five rats each. All groups except the uninduced-untreated (group A) were starved for 24 hours prior to indomethacin administration. After 4 hours of $30 \mathrm{mg} \mathrm{kg}^{-1}$ b.w. indomethacin administration, the groups $\left(A, B, C, D, E\right.$ and F) received once daily oral doses of distilled water $\left(5 \mathrm{ml} \mathrm{kg}^{-1}\right.$ b.w.), cimetidine $60 \mathrm{mg} \mathrm{kg}^{-1}$ (b.w.) and the $S$. virosa extract at doses of 35,70 and $140 \mathrm{mg} \mathrm{kg}^{-1}$ b.w. respectively for $11 \mathrm{days}$. At the end of the treatment, animals in groups B, C, D, E and F were starved for 18 hours then sacrificed. The extract significantly $(p<0.05)$ decreased gastric secretion volume, mean ulcer index, total acidity, total protein and pepsin secretion relative to the induced-untreated rats. The extract significantly $(\mathrm{p}<0.05)$ increased the gastric $\mathrm{pH}$ and total carbohydrate content relative to the induced-untreated. These results were similar to those achieved by treatment with cimetidine. Catalase and SOD activities in the 35, 70 and $140 \mathrm{mg} \mathrm{kg}^{-1}$ b.w. $S$. virosa extract-treated groups were increased significantly $(\mathrm{p}<0.05)$ over the untreated group. Similarly, the extract reversed the indomethacin-induced decrease in reduced glutathione level (GSSH) and the increase in malondialdehyde concentration in the serum. The histological analysis showed positive effect of the extract on the indomethacin-induced ulceration. It was concluded that the extract has anti-ulcerative and antioxidant activity in indomethacin-induced ulcerative rats.
\end{abstract}

Keywords: antioxidant enzymes; anti-ulcerogenic activity; cimetidine; gastric ulcer; ulcer induction

\section{Introduction}

Gastric ulcer contributes majorly to morbidity and mortality in Nigeria and many other third world countries (Agbakwuru et al., 2006). The aggressive secretion of gastric juice contents ( $\mathrm{HCl}$ and pepsin) and the inhibition of blood supply, mucus, prostaglandins synthesis in the stomach (Oloyede et al., 2015) contribute to its aetiology. The secretion which is a physiological event, aggravates the ulcer through cell damage and capillary destruction and inhibited wound healing (Tarnawski and Halter, 1995). Excessive intake of non-steroidal anti-inflammatory drugs (NSAIDs), hereditary predisposition to ulcer and Helicobacter pylori infection, emotional stress amongst other factors contribute to the development of peptic ulcer diseases.

Most of the commonly used antiulcer drugs like gastric antisecretory drugs- $\mathrm{H}_{2}$ blockers (such as cimetidine), anticholinergic agents, proton pump inhibitors (such as
Omeprazole), sucralfate and prostaglandin analogues are shown to have side effects and limitations in clinical practice (Eriyamremu and Iorliam, 2018). Plant-derived remedies have been used in the prevention and treatment gastric ulcers in Nigeria (Maria-Ferreira et al., 2014; Rozza et al., 2014). Carica papaya seed is widely used in the treatment of gastric ulcerations (Oloyede et al., 2015), as well as Momodica species (Vijayakumar et al., 2011) extracts, Musa paradisiaca peels (Ghasi, 2014) and Sesbania species (Bhalke et al., 2010) stem bark extracts amongst others.

Securinega virosa commonly known as Iranje in Yoruba, Njisi-nta in Igbo, Tsuwaawun karee in Hausa, Shim shim in Kanuri and White Berry Bush in English (Neuwinger, 1996); it is one of the great African medicinal plants described as a true omnipotent cure, of which the root (Neuwinger, 1996) is widely used. The plant is widely distributed throughout tropical Africa, but can also be found in India, Malaysia, China and Australia (Dalziel, 
1936). The leaves are used in many parts of Africa in the treatment of fever, body pain, stomach ache, rheumatism, diarrhoea, pneumonia and epilepsy (Neuwinger, 1996).

The objective of this research was to investigate the antiulcerogenic potential of aqueous extract of Securinega virosa leaf as an ameliorative agent against gastric ulcer induced with indomethacin in rats.

\section{Materials and Methods}

\section{Biologicalmaterial}

Securinega virosa plant was identified and authenticated with voucher number UILH/001/166 and samples were deposited at the herbarium of the Plant Biology Department, University of Ilorin, Kwara State Nigeria.

\section{Securinega virosa leaf extract}

Fresh leaves of Securinega virosa were collected, air-dried under shade for two weeks until crispy and then sizereduced into powder with pestle and mortar. Of the powdered leaves, $300 \mathrm{~g}$ was macerated with $3,000 \mathrm{ml}$ distilled water for $5 \mathrm{~h}$ with intermittent stirring. The extract was concentrated on water-bath for 10 days at $45^{\circ} \mathrm{C}$. The yield of the extract (aqueous leaves extract of $S$. virosa) was calculated and the extract was stored in the refrigerator at $4{ }^{\circ} \mathrm{C}$ prior to use. From this, solution of extract was prepared freshly for each study (Magaji et al., 2008).

\section{Phytochemical screening}

Aqueous extract of Securinega virosa was subjected to screening for tannin (Makkar, 1994); saponin (Obadoni and Ochuko, 2001); flavonoid (Boham and KocipalAbyazam, 1994); alkaloid (Harbone, 1973) and total phenols (Singleton and Rossi, 1965).

\section{Chemicals and assay kits}

Indomethacin and Cimetidine were purchased from Alaka-Ola Pharmacy Store, Saki, Oyo State Nigeria. Other chemicals and assay kits used in this research were of analytical grade and they were products of Randox laboratories Co-Artrim, United Kingdom.

\section{Experimental design}

Thirty (30) Wistar rats weighing 160-200 g were used for the study. The animals were allowed to acclimatize to the laboratory conditions for a week. The animals had access to tap water and normal rat chow freely until assigned to individual groups. The rats (30) were weighed individually and divided into six (6) groups of five (5) rats per group.

\section{Animal grouping and treatment was done as follows:}

Group A (un-induced untreated): This group received $5.0 \mathrm{mg} \mathrm{kg}^{-1}$ body weight of normal saline.

Group B: This group received Indomethacin $(30.0 \mathrm{mg}$ $\mathrm{kg}^{-1}$ body weight $)+$ reference drug, Cimetidine $(60.0 \mathrm{mg}$ $\mathrm{kg}^{-1}$ body weight, each dissolved in normal saline).

Group C: This group received Indomethacin $(30.0 \mathrm{mg}$ $\mathrm{kg}^{-1}$ body weight $)+$ extract $\left(35.0 \mathrm{mg} \mathrm{kg}^{-1}\right.$ body weight, drug and extract dissolved in normal saline).

Group D: This group received Indomethacin $(30.0 \mathrm{mg}$ $\mathrm{kg}^{-1}$ body weight $)+$ extract $\left(70.0 \mathrm{mg} \mathrm{kg}^{-1}\right.$ body weight, drug and extract dissolved in normal saline).

Group E: This group received Indomethacin $(30.0 \mathrm{mg}$ $\mathrm{kg}^{-1}$ body weight) + extract $\left(140.0 \mathrm{mg} \mathrm{kg}^{-1}\right.$ body weight, drug and extract dissolved in normal saline).

Group F (INDO-induced untreated): This group received Indomethacin $\left(30.0 \mathrm{mg} \mathrm{kg}^{-1}\right.$ body weight, drug dissolved in normal saline).

The animals except the un-induced untreated group were starved of food for 24 hours, with free access to water only, prior to the administration of indomethacin. After 4 hours of indomethacin administration, the animals were administered daily with the treatments for 11 days consecutively. After the treatments, animal's in-group B, C, $\mathrm{D}, \mathrm{E}$ and $\mathrm{F}$ were starved for 18 hours (with free access to water only) and then sacrificed to check for ulceration.

All the test substances were dissolved in the normal saline solution (Shoaib and Shafiq, 2004).

\section{Evaluation of parameters}

Collection of tissue and gastric juice

After two weeks of treatment, the animals were anaesthetized with diethyl ether and sacrificed by stunning method. Their stomachs were excised carefully by keeping the oesophagus closed and opened along the greater curvature and the luminal contents were removed. Gastric contents from each rat were washed with $5 \mathrm{ml}$ distilled water into a centrifuge tube and centrifuged at $1,000 \times \mathrm{g}$ for $10 \mathrm{~min}$; the volume of the supernatant was expressed as $\mathrm{ml}$ per 100 gram body weight and the centrifuged samples were decanted and analyzed for gastric volume, gastric $\mathrm{pH}$, carbohydrate level, pepsin level and total acidity.

The cleaned stomachs were examined macroscopically after which some were preserved in $10 \%$ formasaline prior to histological studies and others kept in $0.1 \mathrm{M}$ phosphate saline buffer before homogenization. Concentration of reduced glutathione, catalase activity, superoxide dismutase activity and lipid peroxidation (measured by malondialdehyde concentration) were determined using the homogenized stomachs.

\section{Preparation of stomach homogenate}

Immediately after ulcer scoring, whole stomach was ground in a mortar cooled by liquid nitrogen. The stomach tissues $(0.5 \mathrm{~g}$ each) after grinding were then homogenized with ice cold $0.1 \mathrm{M}$ phosphate saline buffer (1:4 (w/v), pH 7.4). The homogenates were centrifuged at $2,500 \mathrm{rpm}$ at $4{ }^{\circ} \mathrm{C}$ for $10 \mathrm{~min}$. The resulting supernatants were frozen to ensure maximum release of the enzymes located in the tissue before being used for the antioxidant assay.

\section{Determination of mean ulcer index}

The excised stomach was viewed under microscope $(x$ 40) to determine the level of ulceration using the method of Raju et al. (2009). The ulcer sores were counted and scored as follows:

Grey colored normal stomach:

Pink to Red coloration stomach:

Spot ulceration:

Hemorrhagic streaks:

Number of Ulcer less than 5: 
198

Number of ulcer more than 5 :

Ulcer with bleeding:

Perforation and edema of gastric wall:

5.0

Mean ulcer score for each animal is expressed as ulcer index:

Ulcer index $(\mathrm{UI})=$ Total ulcer score $/$ Number of animals ulcerated

Gastric acid secretion volume and $p H$ assay

Gastric juice $\mathrm{pH}$ and gastric volume were determined as described by (Kurasawa et al., 2005).

\section{Determination of gastric acidity}

Gastric acidity was determined as described by (Shay, 1945). One $\mathrm{ml}$ of the gastric juice was pipetted and diluted to $10 \mathrm{ml}$ with distilled water. Then, the total acidity of the gastric juice was estimated by titration using $0.01 \mathrm{~N}$ sodium hydroxide and phenolphthalein as the indicator. The result was expressed as the free acid output, which was expressed in terms of $\mathrm{mEq} / \mathrm{L}$ (Prino et al., 1971).

Gastric acidity $=\frac{\text { volume of } \frac{0.01 \mathrm{moi}}{L} \mathrm{NaOH} \times 100}{10}$

\section{Determination of pepsin in gastric secretion}

Pepsin was assayed for as described by (Hirohashi $e t$ al., 1993). The pepsin activity was determined from a standard curve.

$$
\text { Pepsin activity } m g / m i n=\frac{\text { unreacted albumin } x \mathrm{Vt}}{\text { incubated time } x \mathrm{Ve}}
$$

$\mathrm{Vt}=$ Total reaction volume; $\mathrm{Ve}=$ Volume of enzyme used; Unreacted albumin $=$ Concentration of unreacted albumin $(\mathrm{mg} / \mathrm{ml})$;

Estimation of pepsin activity The centrifuged $(5000 \mathrm{~g}$ for 10 minutes) gastric juice $(0.1 \mathrm{ml})$ was added to $1 \mathrm{ml}$ bovine albumin $(0.5 \% \mathrm{w} / \mathrm{v}$ in $0.01 \mathrm{~N} \mathrm{HCl} ; \mathrm{pH} 2)$ and incubated for 20 minutes at $37^{\circ} \mathrm{C}$. A duplicate background control tube (gastric juice blank), in which $1 \mathrm{ml}$ albumin was replaced with $1 \mathrm{ml}$ of $0.01 \mathrm{~N} \mathrm{HCl}$, was simultaneously run. Hydrolysis was stopped by adding $2 \mathrm{ml}$ of $10 \%$ TCA. All of the tubes were heated in boiling water for 5 minutes, and then cooled. After denaturation of the proteins by heating in a boiling water bath for 5 minutes, the precipitate was removed by centrifugation ( $9000 \mathrm{~g}$ for 10 minutes). A total of $1 \mathrm{ml}$ of the supernatant was mixed with $0.4 \mathrm{ml}$ of $2.5 \mathrm{~N} \mathrm{NaOH}$ and $0.1 \mathrm{ml}$ of the Folin-Ciocalteu reagent, and then the volume was adjusted to $10 \mathrm{ml}$ using distilled water. Absorbance was measured at $700 \mathrm{~nm}$. The peptic activity was calculated in terms of micrograms of tyrosine liberated per milliliter of gastric juice (Prino et al., 1971)

\section{Determination of reduced GSH}

The level of GSH in the homogenate was determined using the procedure described by (Ellman, 1959). Briefly, $1.0 \mathrm{ml}$ of stomach mucosa homogenate was added to $0.1 \mathrm{ml}$ of $25 \%$ TCA (trichloroacetic acid) and precipitate was removed by centrifuge at $5,000 \times g$ for $10 \mathrm{~min}$. Supernatant $(0.1 \mathrm{ml})$ was added to $2 \mathrm{ml}$ of $0.6 \mathrm{mmol} / \mathrm{L} \mathrm{DTNB}\left(5,5^{1}-\right.$ dithiobis-(2-nitrobenzoic acid) prepared in $0.2 \mathrm{molL}^{-1}$ sodium phosphate buffer $(\mathrm{pH}$ 8.0). The absorbance was read at $412 \mathrm{~nm}$.

\section{Determination of superoxide dismutase activity}

The activity of SOD in stomach of rats was determined as described by (Misra and Fridovich, 1972).

\section{Determination of catalase activity}

The method of (Beers and Sizer, 1952) was used to determine catalase activity in the stomach homogenates.

\section{Determination of malondialdehyde level}

Malondialdehyde concentration was determined using the method described by (Reilly and Aust, 2001).

\section{Histopathological study}

After thoroughly washing the stomach with distilled in $10 \%$ formaline solution biopsies were collected from these samples. Sections $(5 \mu \mathrm{m})$ were taken from the biopsies and stained with hematoxylin and eosin prior to visual inspection for damage under a light microscope $(160 \times)$ (Oloyede et al., 2015)

\section{Statistical analysis}

Data were expressed as mean \pm standard error of mean $(n=6)$. Comparative analysis was performed between the various groups using analysis of variance (ANOVA) and Duncan multiple range test for the post hoc. Differences were considered at $\mathrm{p}<0.05$.

\section{Results and Discussion}

\section{Phytochemical screening}

Non-steroidal anti-inflammatory drugs (e.g Indomethacin) is one of the major causative factors of gastric ulcer (Suleyman et al., 2010). To offer remedy to gastric ulcer, many pharmaceutical products including histamine (H2) receptor antagonists, proton pump inhibitors, antacids and anti-cholinergics have been used (Singh et al., 2008). However, majority of these treatment drugs pose varieties of undesirable effects (Devi et al., 2007). As a result of the undesirable effects of the synthetics drugs, there is need to find natural drugs possessing antioxidant and anti-ulcerogenic properties which could serve as a bioactive alternative to the synthetic drugs. Medicinal values of plant are attributed to the present of the phytochemicals that are containing in the plant. Phytochemicals especially alkaloids, phenol, flavonoids and tannin contain in this plant are strongly associated to anti-ulcer benefits of a plant (Parag, 2016). Flavonoids are not only free radical scavengers, but are important increasing mucosal prostaglandin content and can decrease histamine secretion from mast cells by the inhibition of histidine decarboxylase (Borrelli and Izzo, 2000). These effects of flavonoids improve mucus secretion. Tannins prevent ulcer development by improving vaso-constricting effects (Aguwa and Nwako, 1988). It is therefore not surprising when we observed that the plant might be able to ameliorate indomethacin-induced gastric ulcer. The enrichment of phenolic compounds within plant extracts is correlated with their enhanced antioxidant activity. Hence, the presence of phenolics in leaf extracts of $S$. virosa may indicate higher potentials in antioxidant and other medicinal properties. 
Recently, it has been reported that the high molecular weight phenolics such as tannins have more ability to reduce or scavenge free radicals (Nagulsamy et al., 2015). Tannins are known to be useful in the treatment of inflamed or ulcerated tissues and they have remarkable activity in cancer (Dharmananda, 2003). Therefore, tannin contents of $S$. virosa may enhance its free radical scavenging, antiinflammatory, and anti-ulcerogenic potential.

\section{Macroscopic examination of the stomach of rats}

Fig. 1 shows morphological visualization of gastric mucosa of rats from each of the experimental group. The gastric mucosa of uninduced-untreated and $60 \mathrm{mg} \mathrm{kg}^{-1} \mathrm{BW}$ cimetidine treated group appeared closely the same with no sign of ulceration, an indication of ulcer healing effects of cimetidine. The gastric mucosa of the groups treated with vary dose of the extract appeared somewhat whitish. Similarly, the gastric mucosa of the groups treated with 35 $\mathrm{mg} \mathrm{kg}^{-1}$ extract and $70 \mathrm{mg} \mathrm{kg}^{-1}$ extract shows no sign of ulceration, an indication of ulcer healing effects of aqueous extract of $S$. virosa leaf. Gastric mucosa of the group treated with $140 \mathrm{mg} \mathrm{kg}^{-1}$ extract and induced-untreated group appear ulcerated with severe injury on the later.

\section{Acid secretory system}

This finding shows anti-ulcerogenic and antioxidant potential of treatment with aqueous extract of $S$. virosa leaf gastric ucer induced with indomethacin in rats. The production of gastric ulcers in rats treated with indomethacin may be linked to the indomethacin inhibitory effect on prostaglandins formation, where the inhibition increases gastric acid secretion, reduces mucosal blood flow and reduces bicarbonate secretion (Wallace, 2008). The aqueous extract of the leaf of $S$. virosa demonstrated a significant anti-ulcerogenic activity by reducing the gastric volume of animals in the group treated with $70 \mathrm{mg} \mathrm{kg}^{-1} \mathrm{BW}$ of $S$. virosa leaf extract and the increase in gastric volume of the untreated indomethacin group is due to increased production of hydrochloric acid as it is evident from the total acidity of the gastric juice
(Sivagnanam et al., 2003) (Table 5). The extract also reduced the gastric acidity in the group treated with $35 \mathrm{mg}$ $\mathrm{kg}^{-1}$ body weight of $S$. virosa leaf and $70 \mathrm{mg} \mathrm{kg}^{-1}$ BW of $S$. virosa leaf (Table 5). Non-steroidal anti-inflammatory drug induced ulcer is mediated through tissue damaging free radicals, which are produced from the conversion of hydroperoxyl to hydroxy fatty acids, which leads to cell destruction. The hydroperoxyl fatty acids are generated from the degeneration of mast cells and generalized lipid peroxidation accompanying cell damage (Prasad et al., 2014).

This study revealed that decrease in the total carbohydrate in the extract-treated groups; suggest significant increase in mucin content on the mucosal cell of the gastric mucosa. The decrease in protein content of the gastric juice of the groups treated with the extract of $S$. viorsa leaf suggests the decrease in the leakage of plasma proteins into the gastric juice (Raj et al., 2013). The increased pepsin activity coupled with increase in total carbohydrate content of the gastric juice in the indomethacin-induced ulcerated rats indicated reduced ability of the mucosal membrane to protect against haemorrhagic erosion, and hence damage to mucosal tissue. This suggests that there is reduced gastric mucosal protection against damage caused by indomethacin. Besides antioxidant action that protects the mucus layer and arrests ulcer progression, drugs that increase the synthesis and secretion of gastric mucus would accelerate gastric ulcer healing. Treatment with $S$. virosa however, facilitated ulcerhealing process associated with decreased pepsin activity and elevated mucin level in the gastric mucosa. This in turn has encouraged speedy wound healing of the ulcerated areas of the mucosal epithelia and shielded the gastrointestinal membrane, thus abrogating the catastrophic influence of indomethacin in the ulcerated rats (Sabiu et al., 2015). This study, however, suggested that Cimetidine may be more effective than $S$. virosa in reducing pepsin activity. The possible ulcer treatment effects of the leaf of $S$. virosa in indomethacin-induce ulcer may be due to increased mucus secretion and reduced pepsin activity.

Table 1. Qualitative analysis of aqueous leaf extract of Securinega virosa

\begin{tabular}{cc}
\hline Phytochemicals & Qualitative result \\
\hline$\underline{\text { Alkaloid }}$ & ++ \\
\hline$\underline{\text { Tannins }}$ & ++ \\
\hline$\underline{\text { Flavonoid }}$ & ++ \\
$\underline{\text { Terpenoid }}$ & ++ \\
$\underline{\text { Saponin }}$ & ++ \\
Anthraquinone & - \\
\hline$\underline{\text { Steroid }}$ & - \\
\hline$\underline{\text { Phenol }}$ & ++ \\
\hline
\end{tabular}

Key: (++) indicates the presence of a phytochemical in sufficient amount, while (-) indicates absence of a phytochemical.

Table 2. Experimental survivor of rats in each group

\begin{tabular}{cccc}
\hline Group & Censored subject & Deaths/event & Percent survival \% \\
\hline Uninduced and untreated & 5 & 0 & 100 \\
$60 \mathrm{mg} \mathrm{kg}^{-1}$ cimetidine & 2 & 3 & 60 \\
$35 \mathrm{mg} \mathrm{kg}^{-1}$ S. virosa & 3 & 2 & 60 \\
$70 \mathrm{mg} \mathrm{kg}^{-1}$ S. virosa & 4 & 1 & 80 \\
$140 \mathrm{mg} \mathrm{kg}^{-1}$ S. virosa & 3 & 2 & 60 \\
$25 \mathrm{mg} \mathrm{kg}^{-1}$ INDO and untreated & 2 & 3 & 40 \\
\hline
\end{tabular}


200

Table 3. Effect of $S$. virosa leaf extract on gastric volume, gastric $\mathrm{pH}$, total acidity and ulcer index in stomach of rats

\begin{tabular}{|c|c|c|c|c|}
\hline Group & Gastric volume (ml) & $\mathrm{pH}$ & TTA\% & Ulcer index \\
\hline Uninduced and untreated & $2.667 \pm 0.133^{a}$ & $3.780 \pm 0.116^{\mathrm{a}}$ & $10.578 \pm 0.690^{\mathrm{a}}$ & - \\
\hline $60 \mathrm{mg} \mathrm{kg}^{-1}$ cimetidine & $4.100 \pm 0.265^{\mathrm{ab}}$ & $4.080 \pm 0.224^{\mathrm{a}}$ & $9.566 \pm 1.012^{\mathrm{a}}$ & $0.667 \pm 0.167^{a}$ \\
\hline $35 \mathrm{mg} \mathrm{kg}^{-1}$ S. virosa & $4.267 \pm 0.203^{3 \mathrm{~b}}$ & $3.820 \pm 0.120^{\mathrm{a}}$ & $10.507 \pm 0.164^{a}$ & $0.667 \pm 0.441^{a}$ \\
\hline $70 \mathrm{mg} \mathrm{kg}-1$ S. virosa & $4.167 \pm 0.033^{3 \mathrm{~b}}$ & $3.600 \pm 0.164^{\mathrm{ab}}$ & $11.732 \pm 0.738^{a}$ & $1.000 \pm 0.500^{\mathrm{a}}$ \\
\hline $140 \mathrm{mg} \mathrm{kg}^{-1}$ S. virosa & $4.400 \pm 0.058^{b}$ & $2.900 \pm 0.110^{b}$ & $17.526 \pm 1.470^{2}$ & $1.667 \pm 0.167^{\mathrm{a}}$ \\
\hline $\begin{array}{l}25 \mathrm{mg} \mathrm{kg}^{-1} \\
\text { INDO and untreated }\end{array}$ & $4.933 \pm 0.120^{\mathrm{b}}$ & $1.980 \pm 0.180^{c}$ & $38.502 \pm 5.693^{\mathrm{b}}$ & $4.750 \pm 0.750^{\mathrm{b}}$ \\
\hline
\end{tabular}

Results are mean \pm S.E.M. $(\mathrm{n}=3)$. $\mathrm{P}<0.05$, were considered statistically significant when compared to uninduced untreated (control) group.

Table 4. Effect of S. virosa leaf extract on pepsin activity, total protein and total carbohydrate level in stomach of rats

\begin{tabular}{|c|c|c|c|}
\hline Group & Pepsin ( $\mu \mathrm{g} /$ tyrosine $)$ & Total protein $(\mathrm{mg} / \mathrm{dl})$ & Total CHO (mg/l) \\
\hline Uninduced and untreated & $14.041 \pm 0.581^{\mathrm{a}}$ & $14.586 \pm 0.049^{\mathrm{a}}$ & $69.385 \pm 2.973^{\mathrm{a}}$ \\
\hline $60 \mathrm{mg} \mathrm{kg}^{-1}$ cimetidine & $16.195 \pm 0.553^{\mathrm{ab}}$ & $16.001 \pm 0.595^{\mathrm{a}}$ & $87.318 \pm 1.399^{\mathrm{b}}$ \\
\hline $35 \mathrm{mg} \mathrm{kg}^{-1}$ S. virosa & $15.527 \pm 0.304^{\mathrm{a}}$ & $17.030 \pm 0.934^{a}$ & $90.255 \pm 0.669^{\mathrm{b}}$ \\
\hline $70 \mathrm{mg} \mathrm{kg}^{-1}$ S. virosa & $19.423 \pm 0.364^{b}$ & $14.050 \pm 0.056^{a}$ & $87.570 \pm 1.678^{b}$ \\
\hline $140 \mathrm{mg} \mathrm{kg}^{-1}$ S. virosa & $23.571 \pm 1.869^{c}$ & $18.551 \pm 1.561^{\mathrm{a}}$ & $95.740 \pm 7.409^{b}$ \\
\hline $25 \mathrm{mg} \mathrm{kg}-1 \mathrm{INDO} \&$ untreated & $31.299 \pm 2.021^{\mathrm{d}}$ & $28.628 \pm 4.516^{\mathrm{b}}$ & $119.284 \pm 0.639^{c}$ \\
\hline
\end{tabular}

Results are mean \pm S.E.M. $(\mathrm{n}=3)$. P $<0.05$, were considered statistically significant when compared to uninduced untreated (control) group.

Table 5. Antioxidant enzymes levels and lipid peroxidation in rat stomach tissues

\begin{tabular}{|c|c|c|c|c|}
\hline Group & $\mathrm{SOD}(\mathrm{mmol} \mathrm{min} / \mathrm{mg} /$ tissue $)$ & $\begin{array}{c}\text { CAT } \\
(\mathrm{nmol} / \mathrm{min} / \mathrm{mg} \text { protein })\end{array}$ & $\begin{array}{c}\text { GSH-Red } \\
\text { (nmol/m mg protein) }\end{array}$ & $\begin{array}{c}\mathrm{LPO} / \mathrm{MDA} \\
(\mathrm{nmol} / \mathrm{m} \text { mg protein })\end{array}$ \\
\hline Uninduced and untreated & $107.072 \pm 2.192^{\mathrm{a}}$ & $4.769 \pm 0.142^{\mathrm{a}}$ & $1.239 \pm 0.076^{\mathrm{a}}$ & $0.033 \pm 0.001^{\mathrm{a}}$ \\
\hline $60 \mathrm{mg} \mathrm{kg}-1$ cimetidine & $93.104 \pm 5.972^{b}$ & $4.4757 \pm 0.077^{\mathrm{a}}$ & $1.088 \pm 0.052^{\mathrm{a}}$ & $0.041 \pm 0.003^{\mathrm{a}}$ \\
\hline $35 \mathrm{mg} \mathrm{kg}^{-1}$ S. virosa & $97.148 \pm 1.133^{\mathrm{ab}}$ & $4.393 \pm 0.046^{\mathrm{a}}$ & $1.095 \pm 0.511^{\mathrm{a}}$ & $0.040 \pm 0.005^{\mathrm{a}}$ \\
\hline $70 \mathrm{mg} \mathrm{kg}^{-1}$ S. virosa & $79.136 \pm 4.214^{c}$ & $2.979 \pm 0.214^{\mathrm{b}}$ & $0.552 \pm 0.0426^{\mathrm{b}}$ & $0.064 \pm 0.001^{\mathrm{b}}$ \\
\hline $140 \mathrm{mg} \mathrm{kg}^{-1}$ S. virosa & $85.973 \pm 3.342^{\mathrm{bc}}$ & $2.553 \pm 0.283^{b}$ & $0.502 \pm 0.085^{b}$ & $0.100 \pm 0.007^{c}$ \\
\hline $\begin{array}{l}25 \mathrm{mg} \mathrm{kg}^{-1} \\
\text { INDO and untreated }\end{array}$ & $44.713 \pm 4.818^{\mathrm{d}}$ & $1.498 \pm 0.245^{c}$ & $0.201 \pm 0.018^{c}$ & $0.129 \pm 0.009^{d}$ \\
\hline
\end{tabular}

Results are mean \pm S.E.M. $(\mathrm{n}=3)$. $\mathrm{P}<0.05$, were considered statistically significant when compared to uninduced untreated (control) group.
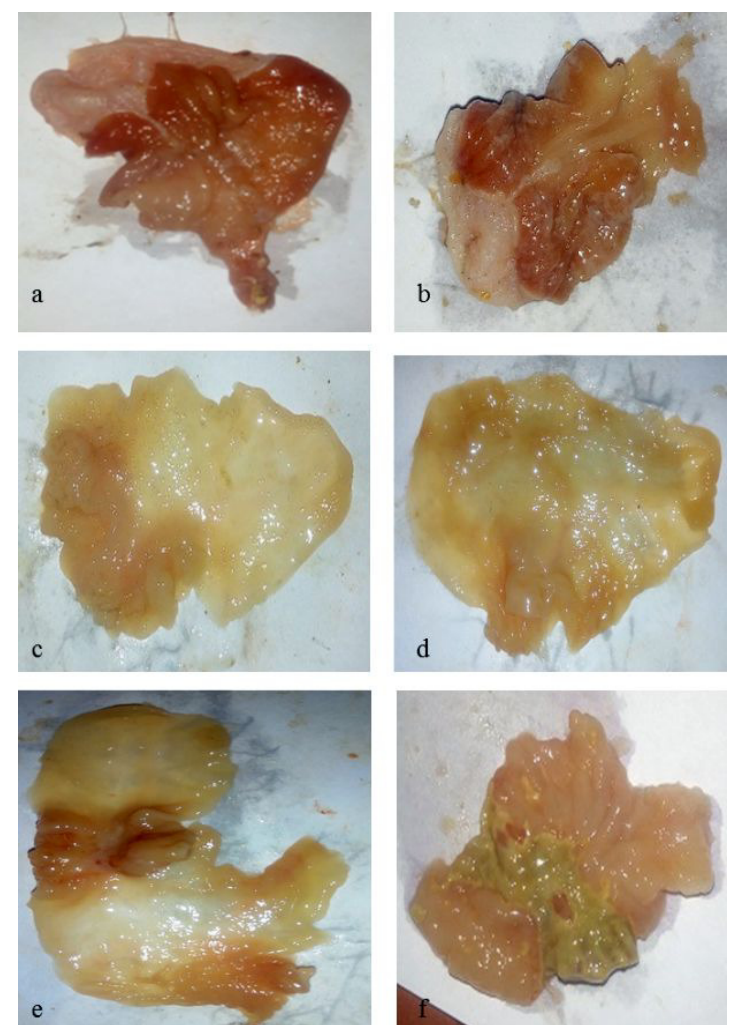

Fig. 1. Morphological visualization of the gastric mucosa of rats: a) uninduced and untreated; b) $60 \mathrm{mg} \mathrm{kg}^{-1}$ cimetidine treated; c) $35 \mathrm{mg} \mathrm{kg}^{-1}$ extract treated; d) $70 \mathrm{mg} \mathrm{kg}^{-1}$ extract treated; e) $140 \mathrm{mg} \mathrm{kg}^{-1}$ extract treated; f) induced \& untreated 


\section{Anti-oxidants system}

Oxidative stress has been shown to be a causative factor in the development and pathogenesis of indomethacinmediated gastric injury (Utsumi et al., 2006). Indomethacin like any other NAIDS have been reported to cause reduction of activities of SOD, catalase, and glutathione peroxidise as well as reduced glutathione concentration in the stomach thereby leading to ulceration (Halici et al., 2005) in the organ.

This study shows that all treatments with cimetidine and $S$. virosa (35 $\mathrm{mg} \mathrm{kg}^{-1}, 70 \mathrm{mg} \mathrm{kg}^{-1}$ and $140 \mathrm{mg} \mathrm{kg}^{-1}$ ) increased the GSH content significantly. This affected the antioxidant defence system positively and reduced gastric damage. GSH protects gastrointestinal tissue lipids from oxidative damage. As shown in previous studies, in gastric tissue damaged by indomethacin, GSH level is lowered after treatment (Albayrak et al., 2015). GSH detoxifies hydrogen peroxide and organic acids chemically; hydrogen peroxide accumulates in the absence of GSH (Dalle-Donne et al., 2003). In the presence of transition metals such as Fe and $\mathrm{Cu}$, hydrogen peroxide reacts with superoxide, resulting in the formation of the highly reactive and cytotoxic hydroxyl radical (Malo and Wilson, 2000).

\section{Lipid peroxidation}

The significantly high levels of MDA in stomach of the induced-untreated group lend credence to previous reports that suggested that free radicals generated by neutrophils may be an important factor increasing the level of gastric ulcer injury (Olaleye and Akinmoladun, 2013). The significant reduction in MDA levels in the extract treated groups suggests its protective action against free radical damage. The extract decreased the MDA content at $35 \mathrm{mg}$ $\mathrm{kg}^{-1}$ more than the other doses of the extract. An increase in MDA content is correlated to an increase in tissue damage.
MDA is the final product of lipid peroxidation and is used to determine the lipid peroxidation levels (Albayrak et al., 2015). This also suggests that the gastro protective potential of $S$. virosa is connected with the reduction in lipid peroxidation in line with a previous report (Olaleye and Akinmoladun, 2013).

\section{Histopathology}

Indomethacin was known for its gastric damage via inhibiting the release of protective factors like cyclooxygenase-1 (COX-1), prostaglandin E2 (PGE2), bicarbonate, and mucus; increasing aggressive factors like acid; and increasing oxidant parameters while decreasing antioxidant parameters (Suleyman et al., 2010). Indomethacin produced gross glandular mucosal damage in rats, an indication of ulcerative lesions, which appeared as eroded mucosa layers in the first 4hours and as wounds in 11days (Fig. 2). Treatment with aqueous extract of Securinega virosa leaf markedly improved the visible eroded mucosa layers and wounds induced by indomethacin in rat stomachs. The histological studies of indomethacin treated rats showed severe degenerated architecture of the stomach, indicating total ulceration of the submucosa layer (Fig. 6). Treatment of rats with aqueous extract of $S$. virosa leaf at dose of $35 \mathrm{mg} \mathrm{kg}^{-1} \mathrm{BW}$ resulted in mucosal layers and gastric cells arrangement similar to the control rats (without ulcer induction) as well as rats receiving cimetidine $60 \mathrm{mg} \mathrm{kg}^{-1}$ $\mathrm{BW}$, these groups showed significant improvement in the treatment of gastric lesions and wound in the submucosa compared to the animals receiving no medicinal intervention after ulcer induction. The observed reduction in the degeneration of the stomach mucosal wall, reduced inflammation and reduced ulceration in the groups treated with the extract may be due to the anti-oxidant and antiinflammatory activity of the extract.
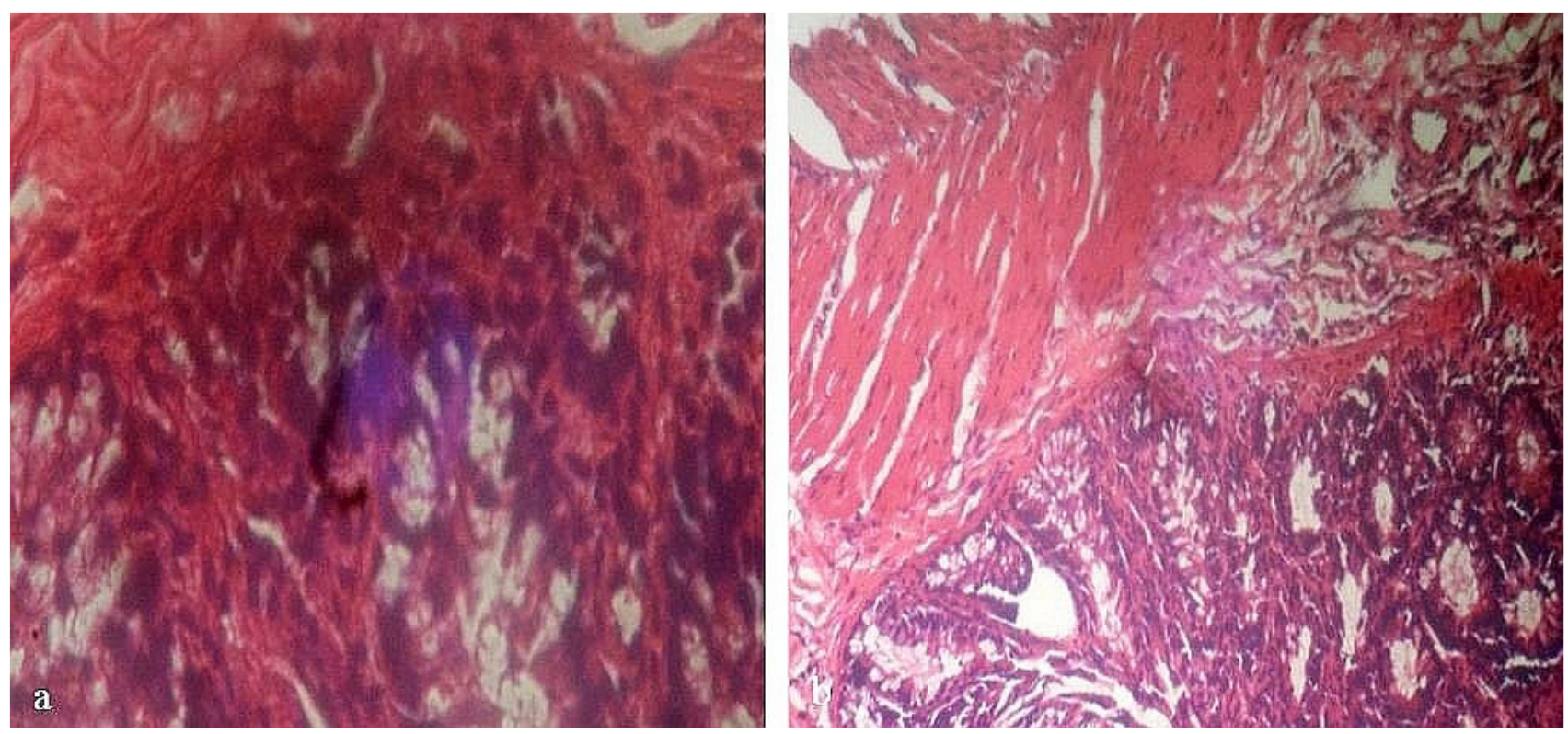

Fig. 2. Induced and treated with $35 \mathrm{mg} \mathrm{kg}^{-1}$ extract. The Photomicrograph shows section of G.I.T. with dense mucosal cells and portion of muscular hyperplasia; a) Mag X 300. The lamina propria is thin lying below extensive area of muscle hyperplasia; b) Mag. X 200 

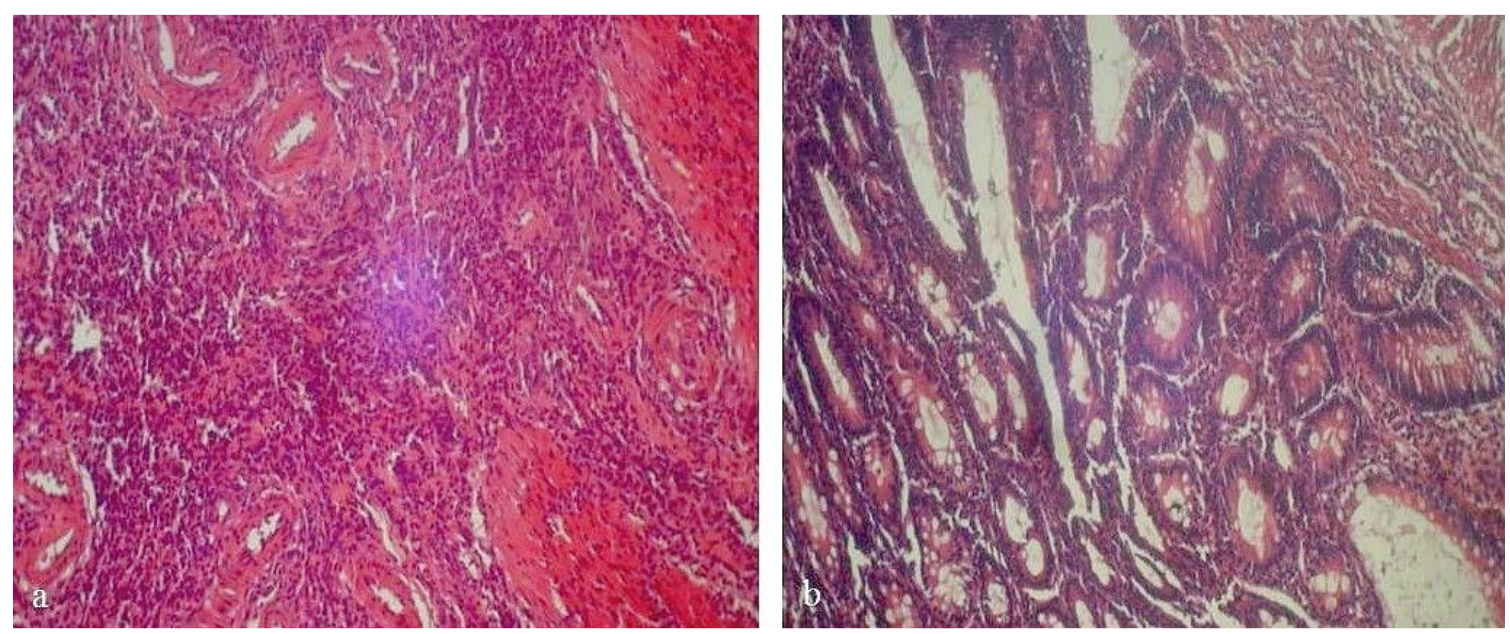

Fig. 3. Induced and treated with $140 \mathrm{mg} \mathrm{kg}^{-1}$ extract. The Photomicrograph shows G.I.T. section with dilated blood vessels and extensive infiltration by lymphocytes; a) Mag. X 200. There is mucosal hyperplasia and mild atypical changes; b) Mag. X 200
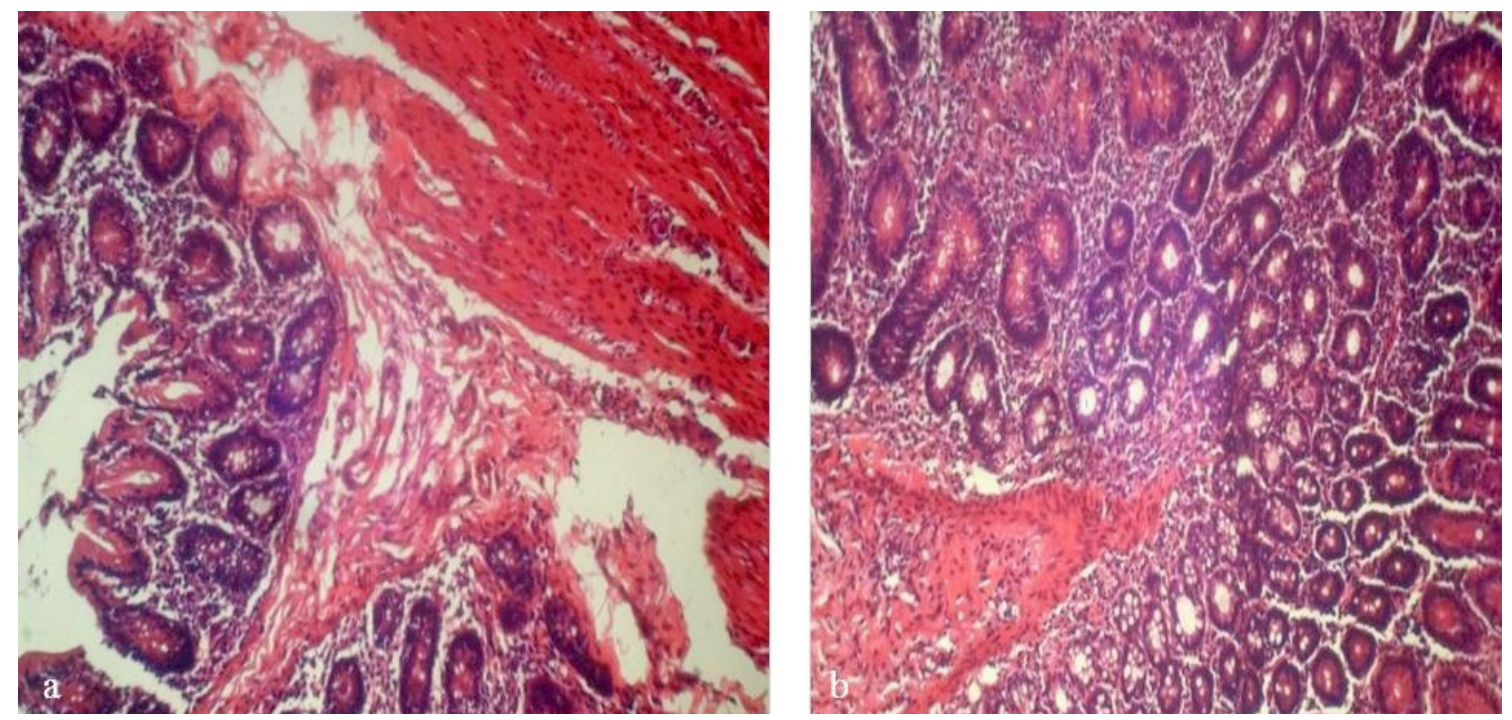

Fig. 4. Induced and treated with $70 \mathrm{mg} \mathrm{kg}^{-1}$ extract. The Photomicrograph shows marked muscle hyperplasia and infiltration with neutrophils; a) Mag. X 200. The mucosa shows mild hyperplasia and is lined by tall cuboidal epithelial cells; b) Mag. X 200
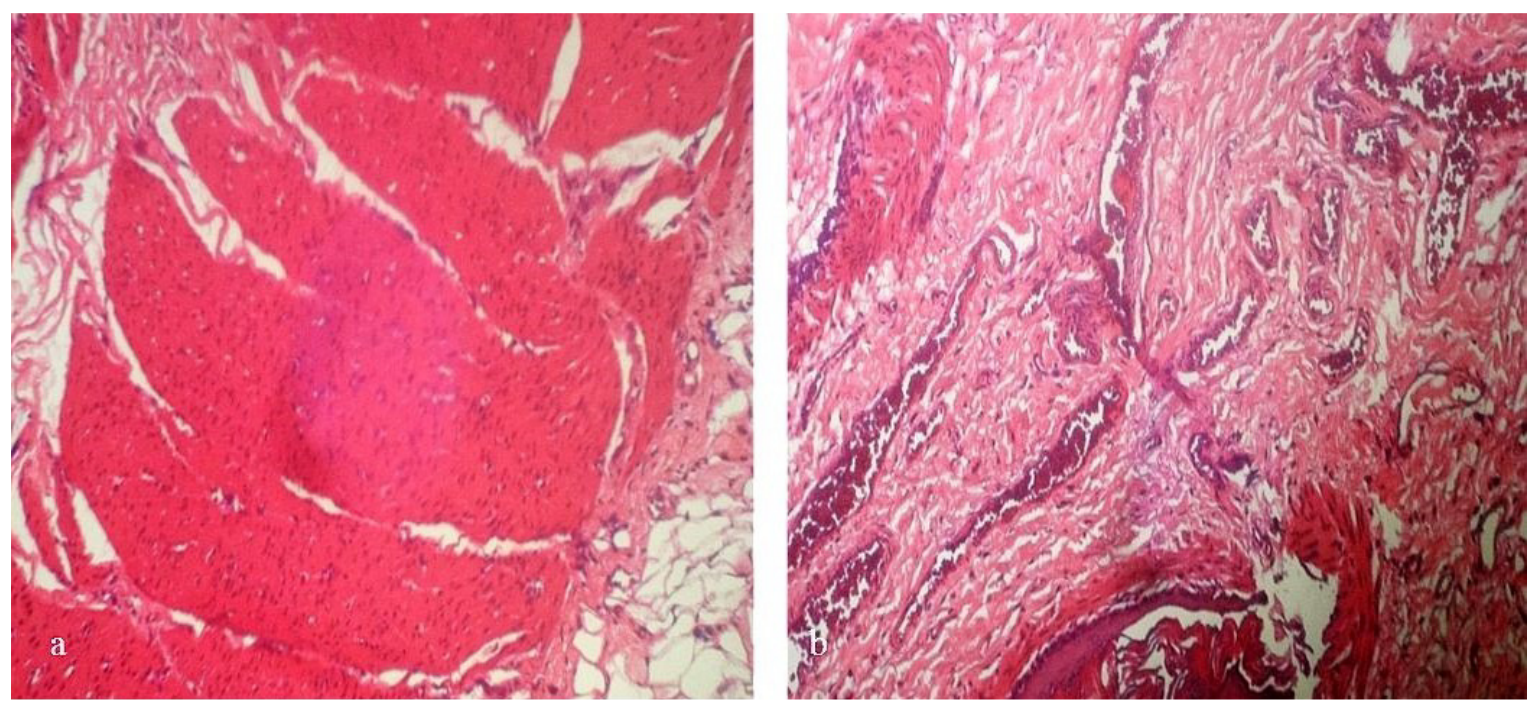

Fig. 5. Induced and treated with $60 \mathrm{mg} \mathrm{kg}^{-1}$ cimetidine: Photomicrograph shows G.I.T. section with marked muscle hyperplasia supported by adipocytes; a) Mag. X 200 and numerous dilated blood vessels; b) Mag. X 200 

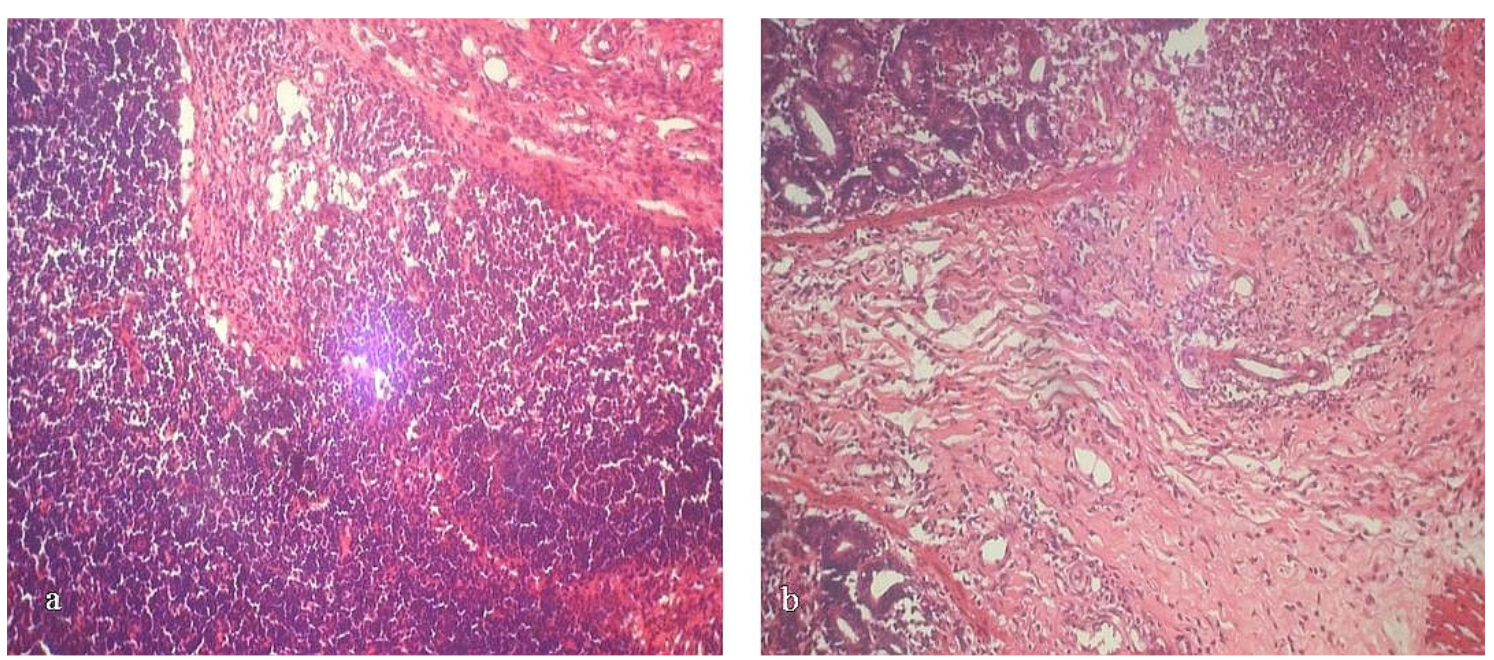

Fig. 6. Induced untreated. The Photomicrograph shows G.I.T. with lymphoid follicular hyperplasia; a) and extensive fibrous muscularis layer populated by chronic inflammatory cells; b) Mag. X 200
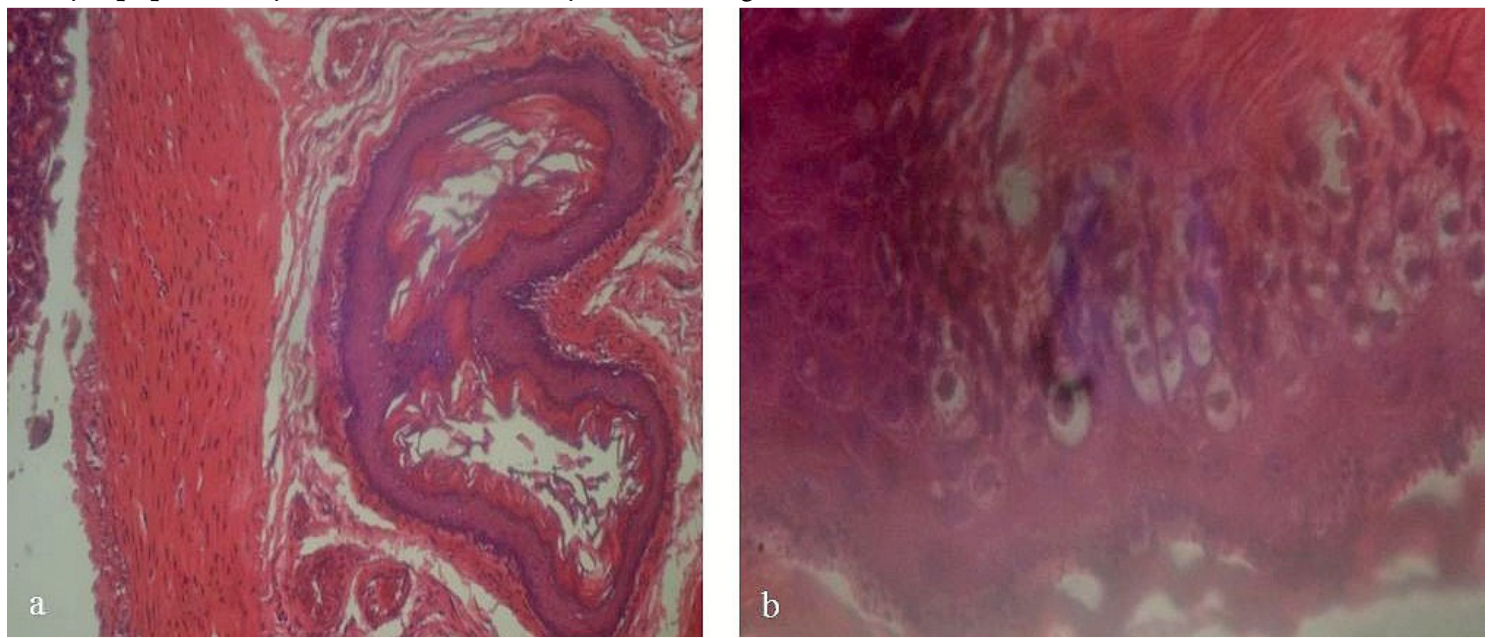

Fig. 7. Uninduced and untreated. The Photomicrograph shows G.I.T. section with longitudinal muscle hyperplasia, keratinized epithelium and with high degree squamation; a) Mag. X 200 and koilocytes with some hyperchromatic cells with dense nuclei; b) Mag. X 300

\section{Conclusions}

From this study, we conclude that the extract has antiulcerative and antioxidant activity in indomethacin-induced ulcerative rats. The plant extract has the ability to reduce gastric volume, gastric acidity, lipid peroxidation and ameliorates gastric mucosal degeneration caused by ulcer and therefore has the potentials for use as an antiulceration agent.

\section{Conflicts of interest}

The authors declare that there are no conflicts of interest related to this article.

\section{References}

Agbakwuru E, Fatusi A, Ndububa D, Alatise O, Arigbabu O, Akinola D (2006). Pattern and validity of clinical diagnosis of upper gastrointestinal diseases in south-west Nigeria. African Health Sciences 6(2):98-103.

Agbakwuru E, Fatusi A, Ndububa D, Alatise O, Arigbabu O, Akinola D (2006). Pattern and validity of clinical diagnosis of upper gastrointestinal diseases in south-west Nigeria. African Health Sciences 6(2):98-103.

Aguwa C, Nwako S (1988). Preliminary studies of the root extracts of Nauclea latifolia Smith, for anti-ulcer properties. Nigerian Journal of Pharmaceutical Sciences 4:16-23.

Albayrak A, Alp HH, Suleyman H (2015). Investigation of antiulcer and antioxidant activity of moclobemide in rats. The Eurasian Journal of Medicine 47(1):32.

Beers RF, Sizer IW (1952). A spectrophotometric method for measuring the breakdown of hydrogen peroxide by catalase. Journal of Biological Chemistry 195(1):133-140.

Bhalke RD, Giri MA, Anarthe SJ, Pal SC (2010). Antiulcer activity of the ethanol extract of leaves of Sesbania grandiflora (Linn.). International Journal Pharmacy and Pharmaceutical Sciences 2(4):206-208.

Borrelli F, Izzo AA (2000). The plant kingdom as a source of anti-ulcer remedies. Phytotherapy Research 14(8):581-591. 
204

Dalle-Donne I, Rossi R, Giustarini D, Milzani A, Colombo R (2003). Protein carbonyl groups as biomarkers of oxidative stress. Clinica Chimica Acta 329(1-2):23-38.

Dalziel J (1936). The useful plants of West Tropical Africa Watmonghs. Idle, London, pp 354355.

Devi RS, Narayan S, Vani G, Devi CSS (2007). Gastroprotective effect of Terminalia arjuna bark on diclofenac sodium induced gastric ulcer. Chemico-Biological Interactions 167(1):71-83.

Dharmananda S (2003). Gallnuts and the uses of Tannins in Chinese Medicine:ITM.

Ellman GL (1959). Tissue sulfhydryl groups. Archives of Biochemistry and Biophysics 82(1):70-77.

Eriyamremu GE, Iorliam EB (2018). Gastroprotective effect of tannin from Schwenkia americana against aspirin-induced gastric ulcer. International Journal of Medicine and Biomedical Research 7(1):32-39

Ghasi $S$ (2014). Evaluation of the anti-ulcer property of aqueous extract of unripe Musa paradisiaca Linn. peel in Wistar rats. African Journal of Pharmacy and Pharmacology 8(39):1006-1011.

Halici M, Odabasoglu F, Suleyman H, Cakir A, Aslan A, Bayir Y (2005). Effects of water extract of Usnea longissima on antioxidant enzyme activity and mucosal damage caused by indomethacin in rats. Phytomedicine 12(9):656-662

Hirohashi M, Takasuna K, Kasai Y, Usui C, Tamura K, Kojima H (1993). General pharmacological profile of the new anti-ulcer drug 3-[[[2-(3,4 dimethoxyphenyl) ethyl] carbamoyl] methyl]-amino-Nmethylbenzamide. Arzneimittel-Forschung 43(5):569-577.

Kurasawa T, Chikaraishi Y, Naito A, Toyoda Y, Notsu Y (2005). Effect of Humulus lupulus on gastric secretion in a rat pylorus-ligated model. Biological and Pharmaceutical Bulletin 28(2):353-357.

Magaji M, Anuka J, Abdu-Aguye I, Yaro A, Hussaini I (2008). Behavioural effects of the methanolic root bark extract of Securinega virosa in rodents. African Journal of Traditional, Complementary and Alternative Medicines 5(2):147-153.

Malo C, Wilson J (2000). Glucose modulates vitamin C transport in adult human small intestinal brush border membrane vesicles. The Journal of Nutrition 130(1):63-69.

Maria-Ferreira D, Da Silva LM, Mendes DAGB, de Almeida Cabrini D, Nascimento AM, Iacomini M, ... Baggio $\mathrm{CH}$ (2014). Rhamnogalacturonan from Acmella oleracea (L.) RK Jansen: gastroprotective and ulcer healing properties in rats. PloS One $9(1): 84762$.

Misra HP, Fridovich I (1972). The role of superoxide anion in the autoxidation of epinephrine and a simple assay for superoxide dismutase. Journal of Biological Chemistry 247(10):3170-3175.

Mozart A, Johannes SB (2014). Erfahrungen der Kursteilnehmerkrankenschwestern [Experiences of the student nurse].Krankenpllegejournal 10:100-120.

Nagulsamy P, Ponnusamy R, Thangaraj P (2015). Evaluation of antioxidant, anti-inflammatory, and antiulcer properties of Vaccinium leschenaultii Wight: A therapeutic supplement. Journal of Food and Drug Analysis 23(3):376-386.

Neuwinger HD (1996). African ethnobotany: Poisons and drugs. Chemistry, Pharmacology, Toxicology: CRC Press.
Olaleye MT, Akinmoladun AC (2013). Comparative gastroprotective effect of post-treatment with low doses of rutin and cimetidine in rats. Fundamental and Clinical Pharmacology 27(2):138-145.

Oloyede HO, Adaja MC, Ajiboye TO, Salawu MO (2015). Antiulcerogenic activity of aqueous extract of Carica papaya seed on indomethacin-induced peptic ulcer in male albino rats. Journal of Integrative Medicine 13(2):105-114.

Parag JA (2016). Secondary metabolites for antiulcer activity. Natural Product Research 30(6):640-656.

Prasad K, Ramesh A, Naresh P, Vinay Kumar I, Naresh D (2014). Evaluation of antiulcer and in vitro antioxidant activity of methanolic extract of Psidium guajava root in albino Wistar rats. International Journal of Phytopharmacology 5:59-67.

Prino G, Pagialunga S, Nardi G, Lietti A (1971). Inhibition of experimentally-induced gastric ulcers in the rat by a new sulfated glycopeptide. European Journal of Pharmacology, 15(1):119-126.

Reilly CA, Aust SD (2001). Measurement of lipid peroxidation. Current Protocols in Toxicology 2.4. 1-2.4. 13.

Rozza AL, de Faria FM, Brito ARS, Pellizzon CH (2014). The gastroprotective effect of menthol: involvement of anti-apoptotic, antioxidant and anti-inflammatory activities. PloS One 9(1):e86686.

Sabiu S, Garuba T, Sunmonu T, Ajani E, Sulyman A, Nurain I, Balogun A (2015). Gastric ucer induced with indomethacination in rats: Protective roles of Spondias mombin and Ficus exasperata. Toxicology Reports 2:261-267.

Shay H (1945). A simple method for the uniform production of gastric ulceration in rat. Gastroenterology 5:43-61.

Shoaib M, Shafiq M (2004). Gastroprotective and antisecretory effect of Nigella sativa seed and its extracts in indomethacin-treated rats. Pakistan Journal of Biological Sciences 7:995-1000.

Singh Khajuria A, Taneja S, Khajuria R, SinghJ,Johri R, Qazi G (2008). The gastric ulcer protective effect of boswellic acids, a leukotriene inhibitor from Boswellia serrata, in rats. Phytomedicine 15(6-7):408-415.

Sivagnanam K, Rajasekaran S, Narayanan V, Subramanian S (2003). Biochemical evaluation of the ulcer curative effect of Aloe vera on experimental rats. Journal of Natural Remedies 3(2):161-165.

Suleyman H, Albayrak A, Bilici M, Cadirci E, Halici Z (2010). Different mechanisms in formation and prevention ofgastric ucer induced with indomethacins. Inflammation 33(4):224234.

Tarnawski A, Halter F (1995). Cellular mechanisms, interactions, and dynamics of gastric ulcer healing. Journal of Clinical Gastroenterology 21:S93-97.

Utsumi H, Yasukawa K, Soeda T, Yamada K-I, Shigemi R, Yao T, Tsuneyoshi $\mathrm{M}(2006)$. Noninvasive mapping of reactive oxygen species by in vivo electron spin resonance spectroscopy ingastric ucer induced with indomethacins in rats. Journal of Pharmacology and Experimental Therapeutics317(1):228-235.

Vijayakumar M, Eswaran MB, OjhaS, Rao CV, Rawat A (2011). Antiulcer activity of hydroalchol extract of Momordica dioica roxb. fruit. Indian Journal of Pharmaceutical Sciences 73(5):572-577.

Wallace JL (2008).Prostaglandins, NSAIDs, and gastric mucosal protection: why doesn't the stomach digest itself? Physiological Reviews 88(4):15471565. 